UDC 821.133.1-14.09 Rimbaud A.

821.133.1:929 Rimbaud A.

https://doi.org/10.18485/ms_zmskij.2020.68.2.6

Др Весна В. Елез

\title{
РЕМБООВИ ЖИВОТИ
}

Артур Рембо није само уклети песник, већ и симбол модерне поезије и побуне. Иако су написане многе студије о његовом животу, у овом есеју желимо да сагледамо познате чињенице и нове закључке до којих су дошли најсавременији аутори. У првом реду издвајамо Рембоове биографије које су написали Грејем Роб (2000) и Сет Виден (2018), иако ћемо се осврнути и на важне закључке познате студије Енид Старки из шездесетих година прошлог века.

Наша намера је да изнова упоредимо Рембоов живот и његово дело да бисмо оправдали његову одлуку да престане да пише поезију када је имао нешто више од двадесет година. Желимо да покажемо зачуђујућу прекогницију, односно сличност пута који је требало да пређе „видовити“ песник из чувеног Рембоовог писма Полу Деменију, и Рембоовог животног пута. Из ове перспективе, однос поезије и живота добија нову димензију.

Кључне речи: Артур Рембо, Пол Верлен, биографија, Илуминаиије.

Генијални песник, „чудо од детета“, велики путник и авантуриста, Артур Рембо је канонизован као уклети песник чија је судбина одавно попримила митске пропорције. Рембо је од најраније младости осећао снажан порив за конкретним испитивањем граница песничке и личне слободе.

Мит о Рембоу не губи на актуелности јер је његов животни пут заиста јединствен: до двадесете године написао је неке од најлепших и најхерметичнијих песама на француском језику. Његова изванредна песничка заоставштина у великој мери је резултат одговорног односа Пола Верлена и неколицине француских песника који су по сваку цену желели да сачувају барем део Рембоовог опуса, знајући његову вредност и јединственост његовог

* Рад је настао у оквиру научног пројекта Института за књижевност и уметност из

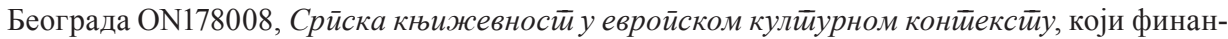
сира Министарство просвете, науке и технолошког развоја Републике Србије. 
метеорског талента. Што се самог Рембоа тиче, знао је да су му три песме објављене у књижевним часописима. После тога, препустио се стихији сопственог темперамента и хаотичног живота у тешким или опасним околностима и, по свему судећи, престао да пише поезију.

Рембоово име остаје јединствено због ране артикулације великог талента и савршеном познавању француске и европске поезије, с једне, и несвакидашњег односа између стварног живота и песничког дела, с друге стране. Готово нико у историји књижевности није успео да и поезију и сопствени живот схвати и доживи апсолутно. Од најбољег ученика у Шарлвилу, преко бунтовника и анархисте који је у више наврата бежао од куће, отпадника и присталице светоназора париских комунара, скандалозне везе са Верленом, Рембо је дословце прешао огроман пут до истраживача и пустолова у потрази за пристојним послом од којег је могао да живи или да се обогати далеко од домовине. Његов живот је попут његове поезије: вечита тежња ка новом и непознатом.

Рембоови биографи су настојали да обелодане све појединости до којих су дошли преко докумената, сећања породице, пријатеља и савременика, преписке и свих могућих извора до којих су их водила истраживања о његовим боравцима у Паризу, Лондону, Бечу, Милану, Келну, Бремену, Хамбургу, Штутгарту, Стокхолму, Копенхагену, Александрији, Адену, на Јави, на Кипру, у Харару, Сомалијској пустињи и у Европљанима непознатим пределима Абисиније.

Његов живот као апсолутно искуство и његова постхумно објављена поезија инспирисали су многе: од предводника авангардних покрета који су у Рембоу видели претечу и генијалног визионара, преко Хенрија Милера који му је посветио књигу Време убища, алудирајући на једно од Рембоових писама, до предводника битника, Џека Керуака, аутора култног романа $\mathrm{Ha}$ $\bar{u} y \bar{u} y$, и рокенрол принцезе Пати Смит која је 2017. године купила реконструисану кућу на имању Рембоових у Рошу.

Многе студије прате несхватљиву авантуристичку и егзистенцијалну кривуљу која се са истока, севера и југа ритмично, периодично, кад год Рембоу понестане основних средстава за живот или га болест и полиција услове, враћала у Шарлвил и на породично имање у Рошу.

После Рембоове смрти у марсејској болици 10. новембра 1891, када га је француска књижевна јавност већ била устоличила као утицајног песника, није било лако веродостојно сачувати његову књижевну и личну заоставштину. Новији биографи указују на штету коју је нанео Рембоов зет Патерн Беришон, подржавајући жељу Рембоове сестре Изабеле да се песник представи као хришћанин и покајник, „приредивши“ Рембоова писма и сопствена сећања у циљу стварања овакве слике о песнику. Врло је мало вероватно да се Рембо на самрти, у тешким халуцинацијама и патњи, исповедио и својевољно примио последњу причест. Познато је да су свештеници и католицизам једна од главних мета гротеске, критике, бласфемије и побуне у његовом делу. 
Друга важна етапа у критичком преиспитивању Рембоове заоставштине отпочела је озбиљном филолошком критиком која је атетезом одстранила неке од песама у прози из Илуминащија које нису биле Рембоове. Анри Бујан де Лакост је у докторској дисертацији из 1949. године изнео и аргументовао једну од најзначајнијих хипотеза о хронологији Рембоовог стваралаштва. Наиме, дуго се веровало, како је и сам песник изјављивао у писмима, да је његова „паганска књига“ Боравак у йаклу његов песнички тестамент. Када је откривен готово нетакнут тираж овог Рембоовог дела, дошло се до закључка да Рембо вероватно није имао новца да га откупи. Раније се веровало да су Илуминачије написане пре Боравка у йаклу, да би се касније закључило да су песме у прози из ове збирке написане делом када и Боравак у йаклу, а делом касније. У прилог овој претпоставци иду енглеске речи у насловима, што упућује на закључак да су неке од њих вероватно настале током Рембоовог боравка у Енглеској са Верленом и касније са Жерменом Нувоом. Иако је датирање Рембоових песама у прози предмет филолошких расправа, данас се углавном сматра да су Илуминације написане у периоду између 1872. и 1875. године. Сузан Бернар нуди најплаузибилнији одговор на ово питање: неке су настале пре Боравка у йаклу, а неке после (BERNARD 1987: LX).

Студије о Рембоовом животу и делу не престају да се нижу. ${ }^{2}$ Међу најрелевантније биографске студије треба уврстити књигу Енид Старки, Арйур Рембо (Enid Starkie, Arthur Rimbaud, New York, New Directions Publishing, 1968). Од новијих биографских анализа издвајамо узбудљиву књигу Грејема Роба, Рембо: биоірафија (Graham Robb, Rimbaud: A Biography, London, Picador, 2000), и студију Сета Видена, Арӣур Рембо, из 2018. године (Seth Whidden, Arthur Rimbaud, London, Reaktion Books, 2018).

Покушаћемо да покажемо да је свако од важних биографа изабрао коjoj ће етапи Рембоовог живота и стваралаштва посветити највише пажње. Из свих студија израња још увек недовољно познат човек и песник, будући да постоје периоди о којима не знамо готово ништа или не знамо довољно. И Сет Виден и Грејем Роб своје студије деле у неколико тематских поглавља. Док код Роба пратимо хронологију, код Видена налазимо критички сагледане и систематизоване чињенице, без Робове опширности, линеарног временског следа и укључивања одређених смелих хипотеза. Виденова књига има још једну значајну врлину: поглавља о Рембоовом животу истовремено су повод за тумачење његове поезије.

\footnotetext{
${ }^{2}$ Види Edward Ahearn, Rimbaud: Visions and Habitations, Berkley, University of California Press, 1983; Yves Bonnefoy, Rimbaud par lui-même, Paris, Seuil, 1987 ; Pierre Brunel, Rimbaud ou l'éclatant désastre, Paris, Seyssel, 1983; André Guyaux, Poétique du fragment : essai sur les 'Illuminations', Neuchâtel, À la Baconnière, 1985; Michel Murat, L'Art de Rimbaud, Paris, José Corti, 2002; Steve Murphy, Le Premier Rimbaud ou l'apprentissage de la subversion, Paris, Lyon, Presses Universitaires de Lyon, 1990; Yves Reboul, Rimbaud dans son temps, Paris, Classiques Garnier, 2009; Sergio Sacchi, Études sur les 'Illuminations' de Rimbaud, Paris, PUPS, 2002; Jean-Luc Steinmetz, Arthur Rimbaud : une question de présence, Paris, Tallandier, 1991; Seth Whidden, Leaving Parnassus : The Lyric Subject in Verlaine and Rimbaud, Amsterdam, Rodopi, 2007.
} 
Наш циљ је да Рембоово стварно „ја“, многоструко попут разних лица лирског , ја“" у његовим песмама и песничкој прози, сагледамо кроз неколико кључних улога које је одиграо у сопственом животу. „ЈА, то је неко други“, чувена Рембоова изјава из писма Жоржу Изамбару, није само полазиште тзв. објективне поезије, већ и напор да се открију сва ,jа“ у њему самом. Рођени номад, Рембо никада није могао да води миран живот ни да се скраси на једном месту. Немир који га је гонио није био само последица његових младалачких и личних импулса у необично бурној адолесценцији, ни његова потреба да спозна најмрачније стране живота. Рембо је предосетио и велике друштвене потресе и трауме.

Станислав Винавер је наслутио шири оквир Рембоовог повлачења из поезије. Винавер кроз Рембоову судбину сагледава судбину читаве модерне поезије. Луцидно је објаснио да „из зачаранога круга Артура Рембоа нема излаза“. Рембо је већ све рекао, и пред њим су стајале три могућности, сматра Винавер: да се врати натраг, у већ речено, да остане пред безданом, или да иде „напред, у вратоломију у помор, у бездану смрт“ (ВинАвеР 1963: 80).

Изузетно нам је стало да покажемо да је млади аутор Пијаноі броgа, који у време писања песме која га је прославила није био видео море, у стварном животу пратио путању исцртану 1871 . године, у чувеном писму Полу Деменију, такозваном Писму Видовитог:

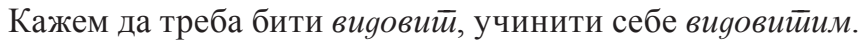

Песник постаје видовит прибегавајући дугом, огромном и смишљеном растиројаваюу свих чула. Свим облицима љубави, патње, лудила; он истражује себе, он кроз себе цеди све отрове, да би сачувао само квинтесенције. Неописиво мучење у коме му је потребна сва вера, сва натчовечанска снага, у коме он постаје више него ико велики болесник, велики злочинац, велики проклетник, - и врховни Учењак!" (Ремьо 2004: 266)

Теоријска потка и песничка самосвест мотивишу овај Рембоов експеримент. Од даљег дословног урањања у искуство на овај начин одустаје пре Боравка у йаклу, чак критикује сопствену поезију у стиху. Оно од чега не одустаје после опробаних улога из писма јесте пут у непознато. Парадоксално, када је Верлену предао рукопис будућих Илуминаиија 1875, Рембо почиње истински живот који је предвидео у Писму Видовитог. Ово је и главни аргумент наше анализе: Рембо је у песничком смислу заиста већ све рекао, и то је сам најбоље знао. Није о реч о каприцу незрелог младића, ни о диктату животних околности. Међутим, песник није професија, већ позив. Рембоов живот је наставио путању коју је одредио Видовитом.

Песник

Рођен 20. октобра 1854. у Шарлвилу, Артур Рембо је био син капетана Фредерика Рембоа и Виталије Куиф, ћерке сеоских земљопоседника. Врло

\footnotetext{
* Превод Николе Бертолина.
} 
рано показује изузетну надареност у школи. Одлично влада латинским и изванредно познаје француску поезију за свој узраст. Такође је јасно да је био свестан сопствених могућности и достигнућа када је, у строгој тајности, младом царевићу пред прву причест послао песму на латинском, 1868. године. Иако песма није била беспрекорна, овај гест сведочи о Рембоовој решености да се, без зазора и посредника, уверен у сопствену вредност, обрати највећим ауторитетима.

У Шарлвилу, на северу Француске, у провинцијском градићу близу белгијске границе, живот није био узбудљив: побожна и строга мајка, коју је Рембо назвао Уста Таме, одсуство оца, који само долази на допусте и поново одлази, сестре су још мале, а старији брат Фредерик незанимљив. Рембо има само шест година када отац напушта породицу. Рембоова мајка себе сматра удовицом и тако се потписује у писмима. Рембоови су у неколико наврата мењали пребивалиште, што је вероватно допринело да Рембо још у детињству сагледа разне социјалне слојеве и упозна различите животне услове. Иако је сама варошица била непривлачна, околни пејзаж, нарочито река Меза и Ардени, пробудили су велику склоност ка природи, шетњи и боравку на отвореном код младог Рембоа. Његов пријатељ и пратилац у овим шетњама био је Ернест Делае, чије су успомене драгоцен извор за биографе и тумаче Рембоове поезије.

Мајка је одувек свим обавезама прилазила са претераним осећајем дужности и реда, што је за даровито дете попут Рембоа представљало не само неподношљиву стегу, већ стално јачало његову жељу да што пре промени средину. Рембоов сан је био одлазак у Париз, али, као што Сет Виден умесно примећује, и само одлазак, било куда (WHIDDEN 2018: 18).

У школи је бриљирао из готово свих предмета, сви професори су знали ко им је вишеструко награђивани ученик, нарочито из латинског, историје и француске књижевности. Прву песму „Ver erat...”(„Било је ирролеће...“) Рембо је написао 6. новембра 1868, тек што је напунио четрнаест година (Исто: 14).

Четрнаестогодишњи Рембо је побрао осам главних награда, и то из следећих предмета: латинске поезије, превода са латинског на француски, латинске прозе, превода са грчког на француски, историје, географије и веронауке. Сет Виден подсећа на Рембоову сналажљивост и обешењачку дрскост када је победио на школском такмичењу из латинског: пошто је требало да преведе на француски део Лукрецијевог дела O йрироgи стивари, петнаестогодишњи Рембо се „ослонио“ на постојећи превод парнасовског песника Силија Придома. Не само да је преписао двадесет шест стихова Придомовог превода, већ их је и дописао, односно „исправио“. Разуме се, нико од професора није приметио овај плагијат. Сет Виден наглашава Рембоову рану склоност ка пастишу и извртању постојећих дела (Исто: 18).

Beћ у раној младости прочитао је завидан број књига. Рембо прву песму на француском, Новоіооищњи йоклон сирочићима, објављује у часопису La Revue pour tous, у јануару 1870, са шеснаест година. Касније, Рембо од најбољег ученика постаје бунтовник, пуши лулу, занемарује школовање, пристојан 
изглед и хигијену, дружи се са маргиналцима и боемима. Презире лицемерје које га окружује, и, попут Флобера, врло конкретно жели да запрепасти буржуја. Песме Засели и Цариници само су неке од многих које илуструју учмалост провинције.

Важну улогу у његовом животу одиграо је Жорж Изамбар, Рембоов професор реторике у гимназији. Он му је био учитељ, али и заштитник, саветник, ментор, једна врста старијег брата и пријатеља. Открио је Рембоу многе песнике и многе књиге које му је позајмљивао. Његове даље рођаке, љубазне старије госпођице Жендр, спасле су Рембоа после првог бекства од куће. Пошто га је Изамбар избавио из затвора у Мазасу где је послат кад је ухваћен без карте у возу за Париз крајем августа 1870, пре него што ће бити враћен мајци, провео је код њих две недеље. Овај боравак у месту Дуе врло је значајан за Рембоов опус, јер је управо од љубазних домаћица, када се вратио код њих у октобру, после бекства од куће у Белгију, Рембо затражио посебан папир на који је желео да запише, односно препише своје песме. Ово је друга чињеница која говори о његовим јасним песничким амбицијама и плановима везаним за штампање дотичних песама. Рембо је препис ових песама оставио Изамбаровом познанику Полу Деменију, младом песнику и издавачу, с којим се спријатељио. Касније је од Деменија тражио да уништи сву његову раније написану лирику коју му је поверио на чување. Срећом, Демени га није послушао.

Уверен у вредност сопствених песама, шеснаестогодишњи Рембо сматра да заслужује место у другом тому Савременог Парнаса. Још у мају 1870. пише Теодору де Банвилу и шаље му три песме за које је веровао да су најбоље и да ће бити објављене: Преgосећај, Oфелија и Credo in unam (последњу песму Рембо је касније преименовао у „Сунце и путт“). Обмањује Банвила да има седамнаест година. На његову жалост, Банвил није прихватио песме тако младог песника за антологију високих критеријума у којој су објављивали већ признати песници. Рембо никада није заборавио овај ударац. Наредне године упућује Банвилу циничну ругалицу парнасовским мотивима и манирима Песнику йовоgом ц̧већа, и потписује се као Алсид Бава. Саркастично пита Банвила да ли је напредовао у односу на прошлу годину.

Неколико околности одредило је даљи ток Рембоовог живота и стваралаштва: бег у Париз, Француско-пруски рат и бомбардовање Мезјера надомак Шарлвила. Гимназија у Шарлвилу се затвара због ванредног стања, Рембо прекида школовање. Један од најлепших Рембоових сонета, Сйавач y gолу, представља конкретан одјек призора које је гледао: уснули војник у Рембоовој песми је заправо мртав.

Први успешни бег до Париза Рембо изводи 25. фебруара 1871, непосредно пре узавреле политичке и социјалне атмосфере Париске комуне: Француска је изгубила рат од Пруске, Наполеон Трећи је са војском заробљен у бици код Седана, Француска је приморана на капитулацију. Многи учесници рата не подржавају овакву одлуку, нарочито после тешких и исцрпљујућих месеци глади и борбе. Из овог отпора настаје Париска комуна, 
18. марта 1871, када побуњеници преузимају власт, управо после Рембоовог повратка у Шарлвил.

Боравак у Паризу, „граду светлости“ и песника, представљао је сурово отрежњење за младог Рембоа. Исцрпљену ратом, француску престоницу мори незапамћена глад током опсаде Париза која је започела у септембру 1870. године. Расуло је свуда, протуве, лопови, бескућници и невољници на сваком кораку. Глад је била толика да су Парижани јели животиње из зоолошког врта (WHIDDEN 2018: 61).

Рембоов боравак у Паризу непосредно пре Комуне представља једно од најрелевантнијих искустава за његов песнички развој. Живео је готово на улици и хранио се отпацима. Егзистенцијална горчина и спознаја тамне стране делују подстицајно на Рембоову лирику. Враћа се пешице у Шарлвил 10. марта. Иако се школа поново отворила у априлу, Рембо се више у њу није враћао. Изгледа да је поново отишао у Париз крајем априла и тамо био и почетком маја.

У Шарлвилу наставља да се дружи са Шарлом Бретањом, кога је упознао кад је отпочео са боемским животом, алкохолом и лутањима. Бретањ је био занимљива појава, бивши цариник, велики критичар свештенства и љубитељ окултног и магије. Овај средовечни човек увек је збијао опсцене шале у кафеу Дитерм где је Рембо био редован гост. Енид Старки истиче да Бретањ није био само ведри шаљивџија и Рембоов друг у пићу, већ је на прави начин подстицао Рембоов таленат, у који је искрено веровао, а не само његове пороке (StARKIE 1968: 98). Под утицајем Шарла Бретања Рембо чита књиге о магији, Кабали, мистицизму које су утицале на његову естетичку теорију о видовитом песнику. Старки скреће пажњу на подршку коју му је пружао Бретањ као саговорник и његов присталица, али и на значај разгранате мреже Бретањевих познанстава међу књижевницима. Бретањ се постарао да неки од њих чују за Рембоа (Исто: 99).

Тако су приче о веома младом песнику из Шарлвила стигле до Пола Верлена. Рембо је истински ценио Верлена, и у разговорима са Изамбаром истицао квалитете његове збирке Галанйне свечаносӣи (Fêtes galantes) из 1866. године. Бодлер је, као што знамо из Писма Видовитог, „прави Бог“, али му је форма, сматра Рембо, „закржаљала“, због утицаја одвише уметничке средине у којој је живео. Верлен је један од истинских песника које Рембо цени и један од оних који су заиста утицали на њега. Спутан загушљивом и неподношљивом провинцијом, Рембо се нада да ће је напустити. Ускоро стиже Верленов позив.

Рембоова песма Пијани броg је последња коју пише у Шарлвилу и спрема се да је покаже најбољим париским песницима. Као што знамо, она представља илустрацију експеримента видовитости. Апсолутна метафора брода који је лирско „ја“"у песми, нове боје, покрет, силовитост и стотину александринаца распоређених у двадесет пет катрена требало је да увере парнасовце и афирмисане песнике у његов несвакидашњи таленат. Управо се то десило у Паризу када га је Верлен представио песничком кружоку 
Vilains Bonshommes. Рембоов геније је бљеснуо, али је његово понашање било неподношљиво и повремено опасно. Презирући све конвенције, плавооки провинцијалац је све запрепастио одсуством манира, ексцентричношћу и бизарним понашањем. Најпре је Верлену нарушио крхки породични склад који је једва успео да успостави када му се родио син. Његова супруга Матилда Моте дуго је покушавала да спасе брак после Рембоовог доласка у Париз. Два песника су започела једну од најскандалознијих веза у историји француске књижевности. Живели су заједно у Паризу, Лондону и Бриселу.

Готово ниједан разговор са Рембоом није могао да тече као конверзација, већ као монолог или опструкција саговорника. Изгледа да је Верлен, који ће му постати љубавник, био редак изузетак. Рембоово безобзирно понашање ускратило му је могућност да ужива било чије гостопримство. Чак је и Банвил, кога није било лако наљутити, и који му је понудио собу на одличној локацији у центру Париза, убрзо схватио да не може да рачуна ни на какву пристојност када је Рембо у питању. То су потврдили и суседи, шокирани призором који су видели на прозору где се Рембо појављивао без одеће.

Повремено боравећи у сликарским атељеима познаника којима његово понашање није сметало или су се врло ретко сретали и срећно мимоилазили, Рембо се касније преселио у здање Hôtel des étrangers, у прибежиште за уметнике сличних интересовања. Дошао је у додир са групом песника који cy се називали Zutistes (од француске речце zut, коју можемо превести као gођавола, или, још прикладније, иври). У духу праве декаденције, њихова поезија је била бунтовничка, цинична, пуна скаредних пастиша. Многе Рембоове песме прате ову естетику. Живећи боемски у Паризу, оглушујући се о конвенције сваке врсте, Рембо наставља своју везу са Верленом, и, како је најавио у Писму Видовитог, „ради на томе да постане видовит“, експериментише са сопственом перцепцијом и издржљивошћу. У истој згради, међу уметницима, станује и Ернест Кабанер, пијаниста. Болестан, оронуо већ у тридесетим годинама због туберкулозе, Кабанер је свирао „за војнике и проститутке“ (Rовв 2001: 133). Његов сабласни изглед овековечио је Мане 1880 , док га је Верлен описао као „Исуса Христа после петнаест година апсинта“" (Исто: 133). Инспирацију за чувени сонет Самойласнищи, илустрацију споја боје и звука, Рембо је вероватно добио управо од њега.

Поред Боравка у йаклу који је започео априла 1873 . и завршио у августу исте године, Рембо је написао и дело Духовни лов (La Chasse spirituelle) које, нажалост, није сачувано. Илуминачије су објављене у часопису La Vogue 1886. године, када се Рембо увелико бавио трговином у Абисинији и највероватније није знао шта се дешавало са његовом заоставштином у Француској.

Биографи преносе сећања савременика који су знали ко је Рембо, и чиме се бавио пре доласка у Африку. Тако је Рембоов послодавац у Адену и Харару, Алфред Барде, на путовању паробродом из Марсеја срео извесног Пола Бурда, новинара, који је ишао у гимназију у Шарлвилу са Рембоом. Пошто презиме није често, Бурд је повезао презиме Бардеовог радника Француза са чувеним школским другом, чије је књижевне почетке оценио као 
изванредне (Rовв 2001: 352). Када је Барде упитао Рембоа о његовим литерарним амбицијама, овај се наљутио и кратко прокоментарисао: „Бесмислено, смешно, одвратно“ (Исто: 353). Уколико писање извештаја за Француско географско друштво о тада још непознатим и неистраженим деловима Абисиније представља више од документа и фактографије, можемо ли сматрати да се будућност поезије преселила у прозу?

\section{Љубавник}

Неодвојив од Рембоове песничке судбине, Верлен је умногоме заслужан за Рембоово песничко сазревање и касније за његово име и заоставштину. Рембо је управо њему поверио рукопис Илуминација у Штутгарту, 1875. године.

Рембоова и Верленова веза почела је драматично и унела раздор у Верленову породицу. Треба рећи да је Верлен и пре породичног живота био врло нестабилан и депресиван. Никада није преболео прерану смрт рођаке Елизе Монкомбл у коју је био заљубљен. Алкохол, поготово апсинт, за њега је био лек против дубоке меланхолије. Верлен је желео грађански живот и посвећеност поезији, али је његов на махове агресивни темперамент изазвао велико подозрење код родитеља његове жене. Матилда, Верленова супруга, истрајно се борила да га поврати. Међутим, после одласка у Лондон и Белгију са Рембоом, ипак је морао да јој призна да његова веза са Рембоом није само необично блиско пријатељство и фасцинација младим песником, већ и хомосексуална веза. Развод је био једино решење. Не треба заборавити да су хомосексуалне везе сматране преступом, уколико би се њихово постојање доказало.

Рембоов и Верленов однос био је турбулентан од самог почетка. Док је још био гост код Верленових, Рембо је учинио све да Матилда схвати да је неће поштедети. Скандализовао ју је својим понашањем, нарочито немаром, одсуством личне хигијене и хотимичном запуштеношћу: на Рембоовом јастуку је први пут у животу видела ваши, вероватно исте оне које је запатио у затвору у Мазасу. Верлен се у више наврата ломио и обећавао да ће се вратити. Чинио је то само када му је био потребан новац и увек у последњем тренутку бирао да се придружи Рембоу, као када су одбегли у Белгију. Боравак у Лондону није био идиличан ни миран. Оба песника су редовно давала огласе у лондонским новинама нудећи часове француског језика.

Живот са Верленом подразумевао је бурне епизоде, због Верленове нестабилности, алкохолизма, посесивности, љубоморе и сталне растрзаности између Лондона и Париза. Верлен у писмима Рембоа често описује као фаталну силу која му није дозвољавала да донесе рационалне одлуке. Описујући Рембоово понашање, од којег је и сам зазирао, с правом га назива демоном. То је једна од улога коју је Рембо одлично одиграо. Мучна и неподношљива ситуација кулминирала је у Бриселу, када је Верлен желео да спречи Рембоа да се врати у Париз. Посесивни и растрзани Верлен је у растројству испалио два хица из пиштоља на Рембоа 10. јула 1873. године. Срећом, метак је Рембоа окрзнуо изнад зглоба леве руке. У суседној соби била 
је Верленова мајка која је Рембоу превила рану. По изласку из хотела, Рембо је видео да се Верлен држи за унутрашњи џеп сакоа. Пошто су заборавили да га разоружају, мислећи да је растројени Верлен још у афекту, Рембо је на улици зауставио полицајца и пријавио Верлена. После мучног испитивања, Рембо је одлучио да одустане од даљег кривичног гоњења, јер је и њему цео случај могао донети бројне непријатности, нарочито због оптужби за недозвољену хомосексуалну везу.

Било како било, Верлен је због покушаја убиства осуђен на две године затвора. Ту се скрушено и покајнички вратио Богу и написао песме које су објављене у збирци Mygpocū (Sagesse). Издржао је казну, изашао из затвора и трудио се да се врати нормалном животу. То му није пошло за руком, пратили су га нови скандали и везе са младићима, алкохолизам и демони. Последњи пут видео је Рембоа у Штутгарту 1875 , када му је Рембо предао рукопис будућих Илуминација.

Иако немамо довољно података о Рембоовом каснијем љубавном животу, изгледа да се определио за жене, нарочито у Абисинији. По свему судећи, чак је размишљао и о женидби. Главна кандидаткиња је, изгледа, била Маријам, висока и витка жена из Абисиније, која је веровато живела са Рембоом у Адену од 1884. до 1886. године. Била је католкиња, слабо је говорила француски, облачила се као европске жене и волела цигарете, по речима Бардеове спремачице која ју је упознала када је дошла да је научи да шије (Rовв 2001: 358). Сачувана фотографија италијанског трговца и Рембоовог познаника Оторина Розе приказује лепу и грациозну жену. Међутим, познато је да је она касније напустила Абисинију и отпутовала у Европу када више није живела са Рембоом.

Било је инсинуација да је Рембо гајио посебну наклоност према младом слуги кога је запослио у Харару, Ђамију Вадаију. Младић је заиста био посебно драг Рембоу, али је то био покровитељски однос, без икаквих хомосексуалних назнака. Млади Ђами је био ожењен и са својом породицом живео у одвојеном делу Рембоове куће. Његова интелигенција и оданост представљале су прави благослов за Рембоа у земљи где није било лако наћи саговорнике, раднике ни сараднике. Рембо му је на самрти оставио три хиљаде франака.

Док је Верлен очигледно гајио хомосексуалне склоности, за Рембоа је епизода са Верленом, изгледа, била једина таква својевољно изабрана веза. Иако Грејем Роб у својој биографији не обраћа нарочиту пажњу на могућа трауматична искуства током Рембоовог првог боравка у Паризу, непосредно пре Комуне, или током Комуне, у књизи Енид Старки ова назнака је једна од кључних непознаница у Рембоовом животу.

Можемо се сложити са њеним закључком да је песма Ойейо срие, првобитно насловљена Измучено срие, коју Рембо шаље у писму Жоржу Изамбаpy 13. маја 1871, енигматична исповест о могућем сексуалном злостављању и силовању које је доживео током боравка у Паризу, у касарни у Вавилонској улици. Ово је одржива хипотеза, имајући у виду чињеницу да је Рембо у 
Паризу јео отпатке, просио на улици и спавао где год би нашао уточиште. Могуће је да је неколико ноћи провео управо у касарни. Песма говори о срцу које крвари, с јасним алузијама на грубу мушку сексуалност која је обешчастила његово срце. Песма се може се схватити и као алегорија, као симболични губитак илузија. Међутим, уколико се бар делимично схвати као аутобиографска, ова песма говори о његовом првом сексуалном искуству. Енид Старки исправно примећује несразмеру између Рембоове ране песничке зрелости и детињег неискуства. Сматрамо да исправно тумачи и Рембоово дубоко разочарање Изамбаровом реакцијом на песму коју је сматрао неуспелом, готово одвратном. Изамбар није схватио да му је ученик послао сопствену исповест и немушто тражио саосећање и нежност:

Вероватно је Рембоа страшно заболело то што га није разумео пријатељ коме је одувек веровао и који је увек, све до тада, саосећао са њим. Сада, у одсудном животном тренутку, само га исмева. Оно што је сигурно јесте чињеница да се после овога Рембо удаљио од Изамбара и није му се више поверавао* (STARKIE 1968: 83).

Такође, Старки врло луцидно уочава кључну сличност између ове песме и Боравка у йаклу: ова песма је „прва дубока рана, прва напрслина која ће довести до потпуног слома у Боравку у йаклу“ (Исто: 80).

Могуће је да је Старки у праву, јер се по повратку у Шарлвил Рембо понашао упадљиво друкчије, очигледно под дејством могуће трауме коју је доживео. Овај догађај донекле може да објасни и његов однос са Верленом. По мишљењу Грејема Роба, нема доказа да је Рембоа „дубоко потресло“ откриће сопствене сексуалности. Говорећи о времену пре везе са Верленом, а после повратка из Париза, такође истиче да нема доказа да је Рембо имао хомосексуалне претензије. „Кварење“ којем се свесно подвргао одласком у окупирани Париз за Рембоа је, по Робовом мишљењу, представљало неку врсту иницијације за све који су себе сматрали побуњеницима и анархистима. Приказивање властодржаца и надређених као хомосексуалаца и педофила није био само Рембоов манир, већ уобичајена социјалистичка ругалица (Roвв 2001: 100). За разлику од Енид Старки, Роб сматра да је Рембо шеретски препричавао како су га детаљно претресали цариници и чувари у затвору. Међутим, ми се слажемо са аргументима које износи Енид Старки. Рембо је носио непробојну маску не само због експериментисања са растројством свих чула и са „видовитошћу“, већ и због дубоке преосетљивости коју није могао да артикулише.

\section{Бунӣовник и йресийуйник}

Иако се младост и адолесценција везују за побуну против свих ауторитета као саставни део човековог одрастања, код Рембоа побуну и анархистичке

* Превела Весна Елез. За потребе овог есеја, уколико друкчије није назначено, наводе из литературе на страним језицима превела је Весна Елез. 
пориве треба схватити у ширем контексту. Због бескомпромисног упуштања у све врсте искуства, под изговором експеримента видовитог песника или по диктату сложеног и осетљивог карактера, Рембо је за авангардне песнике био претеча и апсолутни узор.

Неки тумачи с правом инсистирају на дубљој вези која постоји између Рембоове потребе за бескрајним лутањима и експанзијом, с једне стране, и потребе за новим поретком, за новим друштвеним простором, за силовитим преображајем друштвеног простора за време Париске комуне, с друге.

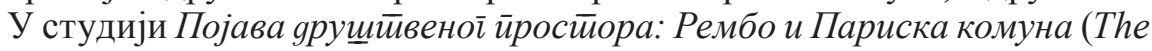
Emergence of Social Space: Rimbaud and the Paris Commune), Кристин Рос указује на протест радника током Париске комуне као на побуну против дубоко укорењених друштвених подела. Комуна је, по њеном мишљењу, прави „хоризонтални“ покрет, бунт против друштвене хијерархије, али и цензуре у култури за време Другог царства. Ова „хоризонталност“ најбоље се огледа у рушењу стуба, „вертикалног“ поретка, подигнутог у славу Наполеонове војске, на Тргу Вендом (Ross 1988: 5).

Рос подвлачи важне просторне аспекте у Рембоовој поезији који одражавају дубљу потребу за преображајем постојећег друштвеног и културног простора. Затвореност привилегованог грађанског простора супротставља се широком пространству које Рембо призива. Она подсећа да Париска комуна, настала када су радници преузели власт 18. марта 1871, представља једну од најдраматичнијих епизода у француској историји. Не треба заборавити, подсећа Рос, да је током Крваве недеље, два месеца касније, на улицама Париза погинуло више радника него у било којој бици у Француско-пруском рату или било којем другом „покољу“ у француској историји (Исто: 4).

Рембоове песме које подржавају идеологију Комуне, попут Париске райне йесме, Руке Жане Марије, Париске орйије, нису једини весници његове горљиве подршке и јасне жеље за великим друштвеним и духовним превратом. Рос истиче да каснија Рембоова поезија врви од топонима и географских одредница: полови и клима, државе, континенти и градови представљају својеврсну мапу друштвеног протеста. Такође, постоји чврста веза између еротског и просторног у Рембоовом делу (Исто: 76). Она сматра да Рембоова поезија најављује друштвени преображај преко именица као што су „додир“, „отвор“, „цепање“ (Исто: 35). Слично размишља и Роберт Сен Клер у студији о Рембоу. Он сматра да је материјалистичка будућност поезије коју је највио у Писму Видовитог управо то: својеврсна верзија Париске комуне примењена на језик. То је једна врста песничке политике, начин да се учествује у борби (Sт. CLAIR 2018: 183).

Знамо да је Рембо одувек желео да учествује у борби за будућност домовине. Желео је да се прикључи Народној гарди, али није желео да се одазове војној обавези. Дух преврата и великог друштвеног преокрета који је осећао пратио је ритам његових песничких визија и слика. Не знамо поуздано да ли је непосредно учествовао у побуни када је, наводно, био у Паризу почетком маја 1871. године. Да ли је догађај описан у песми Ойет̄о срие 
стваран, и у којој мери је ослободио Рембоа идеализоване слике париских побуњеника, не можемо поуздано знати.

Рембо је познавао истакнуте комунаре, нарочито екстремне левичаре и анархисте. Грејем Роб лапидарно преноси утисак који је млади бунтовник Рембо остављао чак и на врло опасне припаднике париског подземља или прогоњене предводнике поражених комунара: „Занимљиво је да је Рембо успео да 'задиви' ове професионалне терористе. [...] Можда су комунари пред млађаним песником деловали конзервативно“ (Rовв 2001: 174). Рембоов анархични полет превазилазио је домете и најзагриженијих идеолога Комуне. Због оваквих познанстава, због проблематичног понашања и везе са Верленом, Рембоа је пратила тајна полиција чак и у иностранству.

Рембо је је једва чекао да својим понашањем шокира и саблазни многе саговорнике. Његови изгреди открили су опасну плаховитост коју је поспешило опијање са Верленом. Жртва овакве Рембоове реакције био је фотограф Етјен Каржа, аутор два најпознатија Рембоова портрета, на кога је Рембо насрнуо на вечери песничког кружока Vilains bonshommes 1871. године. Према једној верзији, пошто му је Каржа упутио коментар који му се није допао, Рембо га је ударио по руци Верленовим штапом са скривеним сечивом, а по другој, сачекао га у ходнику после вечере и убо ножем у стомак (Исто 2001: 152).

Још неколико инцидената изазвала је Рембоова непредвидива нарав. Дезертирао је из холандске плаћеничке војске на Јави, избегао војну обавезу у Француској. Грејем Роб износи податак да је Рембо побегао са Кипра не због посла који није волео, већ због инцидента у којем је једног од радника нехотице каменом погодио у слепоочницу и тако га усмртио (Исто: 306). У Етиопији је ударио једног бакалина, а овај му је узвратио (BORER 1984: 143). У Африци је два пута претучен. Почев од ситних преступа у детињству, бежања од куће, шверцовања дувана у Белгију, путовању возом без карте, Рембо је целог живота испитивао границе слободе.

\section{Пуйник}

Песник и путник су два нераскидиво везана Рембоова ,ја“. Од детињства, од шетњи са Делаеом у раној младости, до првог бега у Париз, касније у Белгију, Рембо је нестрпљиво чекао да се отисне на пут, по могућству пешице, кроз природу. Песме Mоје боемсииво, Преgосећаj, чак и енигматична Вечности, као и многе песме из Илуминаиија, говоре о путовању, ходању, лутању, о природи која се доживљава непосредно, уживо, иако је њена симболика у Рембоовом делу амбивалентна: природа је симбол и живота и смрти.

Колико год нам то изгледало мало вероватно и неспојиво са Рембоовим анархистичким импулсима, ово вишегодишње искуство највише подсећа на монтењевско наслеђе, на динамичко „ја“ које се конституише у покрету. Поред истинског пантеистичког ужитка у самом физичком, чулном контакту са природом (Преgосећај, Зора, Барјаци маја, на пример), Рембоова пер- 
цепција је бивала све изоштренија и префињенија. У сликама које су му се указивале могао је да види боје, обрисе и равни како се граниче или секу. Са узвишења, са осматрачнице, још јасније је могао да сагледа просторне односе и перспективу. После дугог и напорног ходања, у стању потпуне или делимичне исцрпљености, такође је могао да види природу у друкчијем светлу, као при халуцинацији. Иако су музика и сликарство утицали на форму Илуминација, колажи виђених пејзажа и доживљених сензација највише су допринели новој форми његових песама у прози.

Шетње по Арденима, по обраслим стазама према белгијској граници у зору или у сумрак, сменили су боравци у Паризу. Са Верленом одлази у Енглеску, у Лондон, и касније у Остенду први пут у животу види море (Roвв 2001: 182). Иако је живот у Лондону био далеко од лагодног и пријатног, викторијански Лондон је оставио дубок и трајан утисак на Рембоа. Нарочито су важни урбани и просторни елементи које Рембо није могао видети у Паризу. Подстичући његову жеђ за новим формама, за друкчијим и необичним односима у простору, боравак у индустријском Лондону му је послужио као велика инспирација за Илуминащије. Упркос штурим подацима о Рембоовим боравцима у Лондону, сигурно да је овакав град био идеална позадина за његове визије. Сет Виден указује на бодлеровско урбано надахнуће које у Лондону, нарочито преко фигуре моста, ствара нови појам метрополе. То је истинска „објективна поезија“, сматра Виден, будући да су неке од ових песама (Граяови, Мосӣови), лишене људског присуства (WHIDDEN 2018: 102). Исто тако, Рембо ствара утисак сукоба и судара:

Песме стварају утисак модерног градског пејзажа где се спајају урбано и буколичко кроз облике који се сучељавају и сударају. Индустријски зраци сијају кроз метрополу под новим оштрим угловима, заплићу се и окрећу силовитим, аритмичним темпом, док модерни речник ствара нови песнички језик: ови екстатични, сугестивни херојски призори заиста најављују другачију будућност (WHIDDEN 2018: 108)

Упоредо са плановима за даља истраживања, Рембо учи стране језике. Учи шпански, руски, али и немачки, који га је одвео у Штутгарт где је давао часове француског. Касније Рембо учи арапски, а у Абисинији амхарски и језике локалних племена. Учи и италијански, путује у Италију. Пошто му је понестало новца, продаје свој кофер. Одлази возом до границе са Швајцарском. Одатле наставља пешице у Италију. Рембо у Алпима пролази кроз Готардов пролаз и стиже до Милана. Међутим, ходајући тако дуго, разболео се и био приморан да се заустави у Милану. Тамо га је тако изнемоглог и малаксалог прихватила љубазна удовица италијанског трговца вином, попут госпођица Жендр у Дуеју. Код ње је остао две недеље, док се није опоравио. Чим је оздравио, пешице је наставио ка Ливорну, надајући се да ће отићи на острво у Егејском мору где је требало да се придружи песнику Анрију Мерсијеу који му нуди посао у фабрици сапуна (WHIDDEN 2018: 143). Међу- 
тим, у Тоскани га је ударила сунчаница. Француски конзул у Италији се заузео да се безбедно врати кући и послао га после краткотрајног предаха у Марсеј. Рембо се опоравља у болници у Марсеју.

Био је и у Бечу у пролеће 1876. године. Ова епизода се неславно завршила, јер га је претукао и опљачкао бечки таксиста. Полиција га је вратила до француске границе. Одатле је Рембо пешачио до Шарлвила. Надаље, има јасан циљ: жели да избегне војну обавезу у Француској и пронађе посао који није статичан, а уз то је и пристојно плаћен. Стиже у Холандију, где се пријавио у плаћеничку војску која је требало да буде пребачена у тадашњу Батавију, данашњу Индонезију. Рембо плови на Јаву холандским бродом Prins van Oranje. Већ овде Рембо показује све способности које је стекао авантуристичким животом. Животне лекције из париског подземља и са друштвене маргине употпунила је војничка обука легионара. Рембо одлучује да дезертира на Јави, и инкогнито борави у Самарангу. Многе фантастичне легенде настале су услед недостатка фактографских података о овом периоду Рембоовог живота. Неки биографи, непоуздани попут Патерна Беришона, иду тако далеко да тврде да се Рембо крио у индонежанској џунгли и успео да преживи међу егзотичним зверима захваљујући натчовечанским способностима. Једна од књига у којој се преплићу фактографија и претпоставке јесте и симпатична монографија Џемија Џемса Рембо на Јави: изіуубљено йуйовање (Rimbaud in Java: The Lost Voyage) из 2011. године.

Изгледа да је Рембо успео добро да се сакрије и живи од новца који је унапред добио у холандској војсци. По свему судећи, он се укрцао под лажним именом на шкотски брод The Wandering Chief (Луйајући йойлавица) и, после великог невремена код Рта добре наде, у децембру стигао у Квинстаун, у Ирску. Одатле одлази у Париз, вероватно у Шарлвил потом. Кад је зима прошла, отиснуо се у Немачку, у Келн и Бремен, 1877, где је покушао да регрутује војнике за холандску плаћеничку војску из које је дезертирао. Пошто посао није цветао, Рембо путује у Шведску и Данску, највероватније као преводилац у циркусу Лоасе. У септембру се враћа у Шарлвил. Затим из Марсеја намерава да путује у Александрију. На његову жалост, због болести, стомачних проблема, Рембо је брзо враћен у Марсеј. Те године, после опоравка, помаже мајци на породичној фарми у Рошу и кратко се задржава у Паризу.

Не одустаје од пута у Александрију, али сада жели да заобиђе Марсеј и преко Ђенове стигне на обале Црвеног мора. У октобру, преко Швајцарске, поново стиже до Милана и Ђенове пешице преко Готардовог пролаза у Алпима. Сет Виден с правом издваја овај други прелаз преко Алпа као несхватљиво тежак подухват, у позну јесен, кроз снежне сметове. Још је важнији његов закључак о Рембоовој промени перспективе и луталачком искуству. За разлику од слободних лутања по Арденима и Француској у раној младости, Рембо је сада сву своју снагу и издржљивост усмеравао ка савладавању конкретног циља, сматра Виден. То се јасно види из Рембоовог описа ове авантуре из писма од 17. новембра 1878. године. Сет Виден закључује: 
Извештај о мукотрпном проласку кроз Готардов пролаз далеко је импресивнији по опису сурових услова које је издржао него по по неком нарочитом списатељском дару: сву своју снагу усмерио је ка савладавању заслепљујуће снежне олује и сметова који су му сезали до ребара док се пењао на две хиљаде метара надморске висине. Овај подвиг у Готардовом пролазу једнако је задивљујући као и увид у то у каквог се путника Рембо претворио. (WHIDden 2018: 149)

О томе какав је путник Рембо постао сведоче и сећања савременика у Етиопији где је због своје вештине са караванима и велике умешности у трговини постао чувен у целом Рогу Африке. Био је познат по томе што је ишао кроз пустињу само са фесом на глави, а тамо становници Сомалије никада нису залазили, ,jер мозак кључа, лобања пуца и сви који тамо оду никад се не врате“ (Roвв 2001: 359). Каква огромна разлика у односу на Рембоа кога је у Тоскани погодила сунчаница.

После Александрије одлази на Кипар, у Ларнаку, у децембру 1878. године. Британија је преузела управу на Кипру од Отоманског царства неколико месеци пре Рембоовог доласка (Исто: 299). Ту добија посао не као преводилац, како је испрва мислио, већ као надзорник обимних грађевинских радова. Рембо већ овде показује способност да врло ефикасно издаје наређења и надзире радове. Оставио је одличан утисак, иако је био ексцентричан и релативно затворен. Тифусна грозница га је приморала да се врати кући у Рош. Анегдота каже да је Делаеу на постављено питање о књижевности као професији, одговорио „да се више не бави тиме“ (Исто: 302). Рембо се у пролеће 1880. године враћа на Кипар и надзире радове на гувернеровом летњиковцу. Када су услови постали тешки, Рембо одлази без најаве, укрцавши се на брод за Египат.

Тражећи посао и обилазећи градове на Црвеном мору, Рембо се разболео и није имао новца. Већ је прерано оседео, додатно исцрпљен због прележаног тифуса. Имао је среће да се ту затекао један Француз, извесни Требише, ${ }^{5}$ који га је одвео у болницу. Касније га је препоручио младом француском предузетнику из Адена, Алфреду Бардеу, који се бавио трговином кафом и кожом. Када је дошао у Аден, Рембо је одмах приметио хотел претенциозног назива Le Grand Hôtel de l'Univers, у власништву Жила Сијела.

У Адену и касније у Харару, Рембо упознаје трговце, истраживаче, пустолове и авантуристе: двојицу Грка, браћу Ригас, и једног младог грчког истраживача, Сотира, који му је правио друштво при експедицијама у непознато. Ту је био и млади Француз Анри Лисро који је желео да истражи пределе које су насељавала опасна племена око притоке Белог Нила, реке Cобат (Rовв 2001: 312). Пријатељ му је и швајцарски инжењер Алфред Илг који је требало да удари модерне темеље града Менелику Другом, сомалиј-

5 Приметимо иронију Рембоове судбине: презиме Требище (Trébuchet) упућује на француски глагол trébucher, посрнути. 
ском краљу. Треба истаћи да су Абисинија и Црвено море у то време поприште колонијалних претензија и сукоба интереса између Велике Британије, Француске и Италије. Аден је био британски протекторат, Џибути француски, док је Италија претендовала да се избори за своје интересе. Живот у овим пределима био је пун неизвесности и опасности, али и великог потенцијала за трговину и зараду.

Аден је био далеко од егзотичног елдорада, врућине су биле паклене, градом су се ширили јаки непријатни мириси. Рембо се показао као врло успешан и цењен на послу, радницима је издавао наређења на арапском. Једва је дочекао прилику да из Адена оде у нову филијалу Бардеове компаније коју је отворио у Харару, „забрањеном граду“ у Етиопији. Начин на који је Рембо дошао на ново одредиште је фасцинантан. Грејем Роб преноси део атмосфере, истичући опасну руту којом трговци нису ишли: пловили су до луке Зејла, а онда је Рембо, као вођа каравана, требало да опорави неколико мршавих камила, утовари робу уз помоћ локалних носача који су претекли после епидемије малих богиња. Обећана је и помоћ опскурног паше Абу Бекрија, владара Зејле и Тађуре, неке врсте афричког Ал Капонеа, који је контролисао све путеве трговаца робљем и све трговачке руте уз помоћ једанаесторице синова. Роб закључује: „Абисинија није била добро место за трговце - чак ни за мисионаре - ако су хтели да им савест буде чиста и да се врате живи“ (Roвв 2001: 316).

Готово је невероватно у којој мери је Рембо, запослен код трговца кафом, стекао велика преимућства које је одредио за видовитог песника у свом програмском писму. Сва Рембоова , ја“, из париског пакла, из Лондона и Брисела, после алкохола, хашиша, хиљаде пређених километара по Европи, по планинама, равницама, непроходним и прегледним теренима, припремила су га за боравак у Абисинији где је открио Европљанима још увек непознате пределе. Као симболични пандан пијаном броду, Рембо је крочио у Сомалијску пустињу и касније истражио непознати Огаден. Његови извештаји које је слао Француском географском друштву о овим регијама од непроцењиве су вредности. Стил је сувопаран, понекад штур и фактографски, али опсервације одају генијалну руку која је написала Илуминације. Велики значај имају и фотографије које је Рембо снимио у Харару и околини. Планирао је да напише књигу о Абисинији.

Када је дошао у Харар, град ислама, препун просјака, занатлија, оболелих од лепре, прерушених робова, египатских војника и шпијуна, како наводи Роб, Рембо пише мајци да ова област ипак није потпуно нецивилизована: постоји управа, као и египатска војска и коњица. Има кафе, злата и слоноваче, али је море удаљено више од двеста миља, а превоз је скуп (Исто: 321).

Рембо је од мајке поручио превод Курана на француски, иако су му очеве белешке и његови преводи били од користи. Капетан Рембо био је, као и син, радознао, и желео је да научи што више о арапској култури и језику када је као француски војник службовао у Алжиру. Интересовање за стране језике и склоност ка неспутаном, номадском животу Рембо је наследио од оца. 
У Харару Рембо негује сопствени стил, знатно друкчији од европског. Далеко од француске елеганције, Рембо носи лагане тканине које се не копчају. За трговачке експедиције носи импровизован турбан и умотава се у огртач као локално становништво. Ово је била врло мудра мимикрија која је Рембоу омогућила да путује релативно спокојно и не изазива отпор ратоборних племена. Тако постаје незаобилазни посредник у транспорту робе сваке врсте. Поседује сопствени караван, водиче, камиле, муле, складишта за робу. Води и рачуноводство.

Грејем Роб сматра да Рембо у писмима мајци намерно преувеличава непривлачност услова у којима живи и да скрива истину о висини својих прихода, односно износ који је зарадио. Када Бардеов посао опада, Рембо се враћа у Аден. Сигурно је био знатно богатији него што је био спреман да призна. Касније, ради за најстарију трговачку фирму у Адену, за Сезара Тијана. Поново се враћа у Харар и упушта се у ризичну трговину оружјем. Овде све његове ексцентричне врлине и способности долазе до изражаја. Рембо обавештава породицу у писму из 1886. године да намерава да крене у област Шоа и испоручи оружје владару Менелику. Роб истиче да је Рембо једини Европљанин који је успео да са караваном и испоруком оружја пређе преко изузетно опасне територије ратничких племена Данакил и Иса. Чак су и искусни истраживачи и заштићени трговци нађени мртви у пустињи. Наоружани Менелик ће победити италијанску војску у бици код Адве 1896. године и тако одбранити Етиопско царство, односно Абисинију.

Роб подсећа да је енглеско-француски споразум из 1888. године гарантовао независност Харара, и да је, упркос глади, епидемији малих богиња и сталној опасности од побуне, још увек био најбоље место за трговину у Источној Африци (Rовв 2001: 394). Роб, за разлику од ранијих биографа, сматра да испорука оружја краљу Менелику уопште није била финансијски промашај каквим се обично сматра. Зна се да је Менеликов главни управник дочекао Рембоа вешћу да је Лабати, Рембоов партнер у продаји оружја, напрасно умро и дуговао „огроман новац“. То је значило да је Менелик значајно умањио Рембоов хонорар због Лабатијевог дуга. Рембо се жалио и француском конзулу који је требало да посредује у спору због посла у којем је, наводно, изгубио више од шездесет процената добити. Роб сматра да Рембо није рекао истину и да се обогатио после овог подухвата. Претпоставља да је тај новац сакрио или уложио. Његову добит процењује на данашњих сто хиљада британских фунти (Исто: 385).

Рембо је био изузетно способан, успешнији од других, поуздан, вешт и лукав, али није био зао. Уживао је посебан углед и код Европљана у Харару и Адену, и код локалног становништва. Важио је за ексцентричног, особеног, али у суштини поштеног трговца који одлично говори арапски и кога су утицајни људи сматрали пријатељем. Успео је да добије спор против Лабатијеве удовице, а 1887. године пред Менеликом је тужио вођу каравана кога је бранио озлоглашени Абу Бекри (BORER 1984: 143). 
Једна епизода, међутим, баца сенку на његове послове. Због једног писма Менеликовог инжењера Алфреда Илга, у којем он изричито одбија да купи и Рембоу пошаље два роба, без обзира на Рембоову добру намеру у коју није сумњао, сматрало се да је Рембо био умешан у трговину робљем, коју су Британци забранили. Ален Борер одбацује ове наводе. Верује да су неосновани. Као аргумент истиче чињеницу да је локално становништво прихватило Рембоа због његовог коректног односа према њима. У прилог овој тврдњи наводи и мишљење Француза који је живео у Етиопији. Он сматра да је на било који начин Рембо био умешан у трговину робљем, Етиопљани би му сигурно ускратили подршку (BoRER 1984: 236). С друге стране, Грејем Роб сматра да је Илгов тон у писму тон човека који зна да ће полиција пресрести његову преписку са Рембоом, као и да је познато да је Илг имао робове. Роб верује да је Рембо схватао шта су посао и зарада, али да је увек урођенике и локално становништво посматрао као људска бића (Исто: 411). Упоредимо Рембоа вођу каравана са фигуром трговца из Писма Видовитог: „Али ствар је у томе да своју душу треба учинити чудовишном: попут трговаца децом, него шта! Замислите човека који себи по лицу сади и негује брадавице“ (Ремьо 2004: 266). Бежећи од лицемерја цивилизације, Рембо је инстинктивно тежио примордијалном и урођеничком: у Етиопији је био близу сновиђења из Пијаної броgа.

Ипак, ситуација у Харару је бивала све нестабилнија. Рембо је чак два пута претучен, једном због тровања паса који су нападали његова складишта са робом, храном и животињама, а други пут, по свему судећи, због проповедања сопствене верзије делова Курана (Roвв 2001: 408).

\section{Болесник}

Рембо је био зачућујуће отпоран и издржљив у односу на услове у којима је провео већи део свог кратког живота. У Паризу је у више наврата живео у лошим и грозним условима. Уколико додамо алкохол и дуван, свакодневно опијање са Верленом, право је чудо да се чешће није разбољевао. Ако помислимо на стотине, чак хиљаде километара које је превалио пешке, понекад по најсуровијим временским условима, биланс од неколико боравака у болници у Марсеју је одличан резултат. Стоички је подносио несношљиве врућине у Адену, штетне и јаке непријатне мирисе у Харару, где је било лепре, епидемије малих богиња и одличних прилика за заразу сваке врсте. Рембо је већ био прележао тифус, грозницу и стомачне тегобе у више наврата. Међутим, у Харару је добио сифилис. Како и где тачно, није познато. Алфред Барде је јасно видео прве симптоме, афте на Рембоовим устима, које се појављују месец дана после инфекције.

Здравље му је било озбиљно нарушено, али га то није спречило да и даље караваном превози робу, тргује, путује и истражује. Када је планирао нове послове у вези с оружјем, Рембо је осетио интензиван бол у колену десне ноге. Врло брзо, нога је отицала и постајала крута. Схватио је да мора да потражи лекарску помоћ када више није могао да хода. Сам пут до болнице 
у Адену био је тежак и болан, на носилима је путовао до Зејле и помно бележио своју патњу. Британски лекар је поставио погрешну дијагнозу: сматрао је да је реч о поодмаклом стадијуму синовитиса колена (од ове болести је патила Рембоова сестра Виталија, која је умрла 1875. године). Предложио је ампутацију, али је одлучио да сачека неколико дана и види да ли ће се оток повући (Roвв 2001: 422). После шест дана, стање се није поправило. Доктор му је саветовао да се врати у Француску. Рембо паробродом долази у Марсеј, где је смештен у болницу 22. маја 1891. године. Ту су му лекари ампутирали ногу. Исправна дијагноза била је рак костију, односно остеосарком. Мајка и сестра су одмах допутовале у Марсеј. За Рембоа је ампутација била страшна вест. У Паризу новине пишу да је откривено да песник Артур Рембо живи у Африци.

Иако је веровао да ће се опоравити и вратити у Африку, стање се није поправило ни после боравка у Рошу. Напротив. Поново је био у болници, трпео страшне болове, имао халуцинације. Последње дане провео је у болници у Марсеју, где је умро 10. новембра 1891. године. Имао је тридесет седам година.

Рембоови последњи месеци живота истински су тужни и трагични. Вероватно се искрено надао да ће, иако болестан и изнемогао, ипак моћи да хода. Ноге су биле једина спона са слободом. Можда је Рембо ипак веровао да песници, чак и када постану трговци, нису обични смртници, или да их судбина не кажњава овако сурово. Да ли су му се у халуцинацијама вратиле речи из писма Видовитог, по којима је песник, чак и ако полуди, посебно биће, јер је стигао до непознатог, јер је, чак и ако га лудило спречи да их разуме, оне те слике ипак видео? Нажалост, то никада нећемо сазнати.

\section{ИЗВОРИ}

Ремьо, Артур. Писмо Полу Деменију. Сабрана йоейска gела. Превод, предговор и напомене Никола Бертолино. Београд: Раideia, 2004, 265-269.

Rimbaud, Arthur. Euvres. Édition de Suzanne Bernard et André Guyaux. Paris: Classiques Garnier, 1987.

\section{ЦИТИРАНА ЛИТЕРАТУРА}

Винавер, Станислав. Ускоково бекство или есеј о Артуру Рембоу. У: Наgірамайика. Београд: Просвета, 1963, 77-101.

Bernard, Suzanne. Le Problème des Illuminations. Y: Arthur RIMBAUD. Euvres. Édition de Suzanne Bernard et André Guyaux. Paris : Classiques Garnier, 1987, V-LXIV. 
Borer, Alain. Rimbaud in Abyssinia. Rosemary Waldrop (прев.). New York: William Morrow and Company Inc., 1984.

James, Jamie. Rimbaud in Java: The Lost Voyage. Kuala Lumpur, Didier Millet, 2001.

Roвв, Graham. Rimbaud: A Biography. London: Picador, 2001. Прво издање 2000.

Ross, Kristin. The Emergence of Social Space. Rimbaud and the Paris Commune. Minneapolis: University of Minnesota Press, 1988.

Starkie, Enid. Arthur Rimbaud. New York: New Directions Publishing, 1968.

St.ClaIR, Robert. Poetry, Politics \& the Body in Rimbaud: Lyrical Material. Oxford: Oxford University Press, 2018.

WhidDEn, Seth. Arthur Rimbaud. London: Reaktion Books, 2018.

Vesna V. Elez

\section{RIMBAUD'S LIVES}

Summary

The iconic figure of modern poetry, Arthur Rimbaud led a truly unique life. His biography is as mesmerizing and adventurous as his poetry. The young genius from Charleville had written some of the most beautiful verses in French poetry by the age of twenty, when he allegedly stopped writing.

We will argue in support of his decision to abandon his career as a poet and to opt for a tumultuous, uncertain and nomadic life that eventually led him to become a merchant in Abyssinia. We shall rely on most recent accounts of Rimbaud's life, Graham Robb's book, written in 2000, and Seth Whidden's study, published in 2018. We shall also include Enid Starkie's study of reference. Our aim is to draw attention to the peculiar precognition of his own life in the famous letter he wrote to Paul Demeny in 1871, describing the poet as a Seer, insisting on all the experiences he had to undergo. His signature poem "The Drunken Boat" uncannily heralds the path he would take in his quest for the total experience. As his life unfolded, even though he had abandoned his poetic experiment, he seems to have followed the path of his poetic journey.

Универзитет у Београду

Филолошки факултет

Катедра за општу књижевност и теорију књижевности

vesna.elez@fil.bg.ac.rs 